\title{
Ammattiin opiskelevat liikkeelle
}

\section{Europass-todistus käytössä kohta vuoden}

\author{
Maisa Saarinen
}

\section{Europass on asiakirja, jonka avulla todennetaan toisessa \\ EU- tai ETA-maassa suoritettu ammattiin valmentava \\ koulutusjakso. Suomessa tämä kansainvälinen \\ koulutuspassi tunnetaan jo varsin hyvin, mutta monessa \\ EU-maassa se on vielä vieras.}

Eurooppalaiset korkeakouluopiskelijat ovat jo pitkään liikkuneet aktiivisesti opiskelija- ja työharjoitteluvaihdoissa ulkomailla. Ammattiin opiskelevien liikkuvuus on ainakin vielä huomattavasti vähäisempää. Euroopan unioni on viime aikoina kiinnittänyt asiaan erityistä huomiota ja aloittanut useita hankkeita edistämään ammatillisten opiskelijoiden ja ammattitaitoisen työvoiman liikkuvuutta. Yksi hankkeista on vuoden alussa käyttöön otettu Europass-todistusjärjestelmä.

Europass-todistus on asiakirja, jonka avulla todennetaan toisessa EU- tai ETA-maassa suoritettu ammattiin valmentava koulutusjakso. Jaksosta käytetään nimitystä eurooppalainen koulutusjakso, ja se hyväksytään aina osaksi kotimaista koulutusta. Tavoitteena on, että jaksoon kuuluu työssäoppimista, työharjoittelua tai sellaista koulutusta, johon sisältyy myös käytännön töitä. Jakso voidaan suorittaa esimerkiksi opiskelija- tai harjoittelijavaihdon aikana.

Europass-todistusjärjestelmä perustuu Euroopan unionin neuvoston 21.12.1998 tekemään päätökseen (1999/51/EY), ja sen toimivuutta ja vaikutuksia opiskelijoiden liikkuvuuteen seuraa
Euroopan unionin komissio. Suomessa europassiasioiden valtakunnallisena yhteystahona toimii opetushallitus.

Europassista on pyritty luomaan helppokäyttöinen ja joustava, jotta se soveltuisi mahdollisimman monenlaiseen ammatilliseen koulutukseen, myös oppisopimuskoulutukseen. Suomessa europassi voidaankin antaa ammattiin valmentautuville kaikilla koulutustasoilla: toisen asteen ammatillisessa koulutuksessa, korkea-asteella sekä ammatillisessa lisäkoulutuksessa.

Joustavaa europassin käytössä on myös se, ettei eurooppalaisille koulutusjaksoille ole määritelty vähimmäispituutta. Lähettävä oppilaitos päättää, millainen koulutusjakso voidaan perustellusti hyväksyä tutkinnon osaksi.

\section{Mitä europassiin merkitään?}

Europassiin merkitään perustiedot opiskelijasta ja hänen koulutuksestaan ja koulutuksen järjestäjästä lähtömaassa. Eurooppalaisesta koulutusjaksosta täytetään oma osuutensa, jossa annetaan tiedot ulkomaisesta yhteystahosta sekä jakson si- 
sällöstä, kestosta ja sen aikana hankitusta työkokemuksesta tai koulutuksesta. Lisäksi todetaan, että suoritettu eurooppalainen koulutusjakso on osa tutkintoon johtavaa koulutusta.

Europassi on käytössä samanmuotoisena kaikissa EU- ja ETA-maissa. Se täytetään aina vähintään kahdella kielellä, joista toinen on koulutuksen kieli, suomalaisen opiskelijan kohdalla tavallisesti suomi tai ruotsi. Ulkomainen yhteistyökumppani kirjoittaa selvityksen opiskelijan europassiin omalla kielellään tai välittäjäkielellä, esim. englanniksi. Suomessa selvitys käännetään opiskelijan europassiin suomeksi tai ruotsiksi.

\section{Europassin edut}

Europassin käyttö edellyttää, että lähettävä ja vastaanottava osapuoli sopivat etukäteen harjoittelun sisällöstä ja tavoitteista ja että opiskelijalle nimetään jakson ajaksi ohjaaja neuvomaan ja tukemaan sekä valvomaan tavoitteiden toteutumista. Kun asioista sovitaan selvästi etukäteen, nuorikin opiskelija voi lähteä ulkomaille turvallisin mielin.

Europass-todistusjärjestelmän ansiosta lähtömaan koulutuksen järjestäjät pystyvät entistä paremmin seuraamaan opiskelijoidensa ulkomaisia koulutusjaksoja, vaikuttamaan niiden sisältöön ja kehittämään omaa kansainvälistä toimintaansa.

Euroopanlaajuisesti tunnettu yhtenäinen asiakirja antaa luotettavaa ja helposti vertailtavissa olevaa tietoa opiskelijan koulutuksesta ja siihen sisältyvistä eurooppalaisista koulutusjaksoista. Siten siitä voi olla opiskelijalle hyötyä työnhaussa sekä kotimaassa että ulkomailla.

\section{Ensimmäisen vuoden kokemuksia}

Suomessa sekä opiskelijat että koulutuksen järjestäjät ovat ottaneet europassin myönteisesti vastaan, ja europassi tunnetaan meillä jo hyvin. Ensimmäisen vuoden aikana opetushallituksesta tilattiin noin 1500 europassia, ja parhaillaan odotetaan palautteita ensimmäisen vuoden eurooppalaisista koulutusjaksoista.
Jo saapuneiden yksittäisten palautteiden perusteella monikielistä europassia on pidetty hieman hankalana täyttää eikä sitä vielä tunneta kaikkialla yhtä hyvin kuin Suomessa. Opiskelijat tuntuvat kuitenkin olevan yksimielisiä siitä, että europassista on heille tulevaisuudessa hyötyä.

\section{Lisätietoa}

Perustietoa europassista löytyy opetushallituksen ja Euroopan komission www-sivuilta osoitteista http:// www.oph.fi/europassi ja http://europa.eu.int/comm/ education/europass/index-en.html. Opetushallituksesta on lisäksi saatavana suomen-, ruotsin- ja englanninkielisiä esitteitä sekä näytteitä europassista.

Uusinta tietoa europassista, käyttäjien kokemuksia sekä käytännön neuvoja on tarjolla opetushallituksen järjestämässä seminaarissa Helsingin Paasitornissa 7.2.2001. Seminaarissa käsitellään ammattiin opiskelevien kansainvälistä liikkuvuutta, ja europassin lisäksi aiheina ovat liikkuvuuden yleiset edellytykset, ammatillisten tutkintojen kansainvälinen vertailu sekä tutkintotodistukset ja niiden kansainväliset liitteet.

Opetushallitus

PL 380, 00531 HELSINKI

Puh. (09) 774 775, Faksi (09) 77477201

europassi@oph.fi 